\title{
Kentsel Çevrenin Algısı: Muratpaşa İlçesi Örneği
}

\author{
Ayşe Gülnur HAMMALOĞLU ${ }^{1 *}$, Murat AKTEN ${ }^{2}$ \\ ORCID 1: 0000-0001-6432-2103 \\ ORCID 2: 0000-0003-4255-926X \\ ${ }^{1}$ Süleyman Demirel Üniversitesi, Fen Bilimleri Enstitüsü, Peyzaj Mimarlı̆ı̆ Ana Bilim Dalı, 32260, Isparta, Türkiye. \\ ${ }^{2}$ Süleyman Demirel Üniversitesi, Mimarlık Fakültesi, Peyzaj Mimarlığı Bölümü, 32260, Isparta, Türkiye. \\ *e-mail: aysegulnurhammaloglu06@gmail.com
}

Öz

Geçmişten günümüze doğa içerisinde fiziksel çevreler, kentler oluşturulurken insanların tercihleri topoğrafik yapı, iklim özellikleri, erişim kolaylığı, doğal kaynaklar, doğa ve çevre ilişkisi gibi yer oluşturma ilkeleri etrafında temellenmektedir. Fiziksel öğelerin niteliklerinin yanı sıra taşıdıkları anlamları ve nasıl algılandıkları da oldukça önemlidir. Bu bağlamda çevrenin yalıızca insanın biyolojik gereksinmelerini karşılayan işlevsellik değil, aynı zamanda psikolojik, entelektüel gereksinmelerini de karşılayan estetik nitelikler de taşıması gerekmektedir. Bu çalışma ile estetik niteliği kazanmış kentlerin, kent bilincinin geliştiği daha huzurlu, daha sağıkık kentsel yaşam alanları oluşturacağı hipotezinden yola çıkılmıştır. Kullanıcıları tarafından çevresel algı ve kent estetiğine yönelik görüşlerin araştırılması amacıyla, Antalya kentinde aktif olarak kullanılan Güllük Caddesi ve devamında yer alan Cumhuriyet Meydanı, Kapalı Yol mevkileri çalışma alanı olarak belirlenmiştir. Çıkan sonuçlarla, kentsel çevre algısı ve estetiğine yönelik düzenlemeler ve önlemler alınarak, kentin çağdaş yaşamın gereklilikleri ile uyumlu ve yaşanabilir alanlar olarak gelecek kuşaklara aktarılmasına katkı sağlanacaktır.

Anahtar Kelimeler: Kent, çevre, estetik, kentsel estetik, Antalya.

\section{Perception of the Urban Environment: The Case of Muratpaşa District}

\section{Abstract}

From the past to the present, while physical environments and cities in the nature are being established, people's preferences have been based on the principals of constructing sites such as topographic structure, climate characteristics, ease of access, natural resources, and nature and environment relations. In addition to the features of physical elements, the meaning they have and how they are perceived are also very important. In this context, the environment must bear not only the functionality that meets the human biological needs, but also the aesthetic qualities that meet the psychological and intellectual needs. With this study, the hypothesis that the cities, which have gained the aesthetic quality, will create more peaceful and healthy urban living areas where city consciousness develops has been proposed. In order to investigate the viewpoints about environmental perception and urban aesthetics by its users, Güllük Street which is actively used in the city of Antalya and the Cumhuriyet Square located in the following section have been determined as the study area of the Kapalı Yol positions. With the results obtained, arrangements and measures for urban environment perception and aesthetics will be ensured and the city will be harmonized with the requirements of contemporary life and contribute to its transfer to future generations as habitable areas.

Keywords: Urban, environment, aesthetics, urban aesthetics, Antalya.

Atıf: Hammaloğlu, A.G., Akten, M. (2019). Kentsel Çevrenin Algısı: Muratpaşa Illçesi Örneği. Mimarlık Bilimleri ve Uygulamaları Dergisi (MBUD), 4 (2), 172-182.

DOI: $\underline{10.30785 / \mathrm{mbud} .589442}$ 


\section{Giriş}

Endüstri devrimi beraberinde kentleşmeyi de getirmiş, kentte bulunan iş imkânları, sosyal ve kültürel olanaklar insanlara cazip gelerek kırdan kente göçü her geçen gün hızlandırmıştır. Modernizm döneminde modern kent unsurlarını yansıtan altyapı çalışmaları yapılmıştır. Yapılan yeni ve gelişimci çalışmalara rağmen birçok problem de ortaya çıkmıştır. Bu sorunları; hızlı kentleşme ile nüfus yığılmaları, arsa spekülasyonları ve çarpık kentleşme olarak özetlemek mümkündür.

Kentin kalabalıklaşması, mekânsal olarak giderek büyümesi, kapitalist dizge içinde, mekânda "daha işlevsel" alanların ortaya çıkması, alınıp satılması, bunlara bağlı olarak "rant" sorununu da ortaya çıkarttı̆̆ını gösterilmektedir. Bu nedenle de 20. yüzyılın sanayi kenti, artık eskisinden farklı olarak, daha kozmopolit, işçilerin giderek kalabalıklaşmaya başladığı ve örgütlendiği, yaşam koşullarının bozulduğu son derece sorunlu bir kenttir (Sevinç, 1999).

Modernizm döneminde (1884-1914) çözüm olarak en çok üzerinde durulan ise "planlama" kavramı olmuştur. Olumsuz şartları aşmak için planlama yaklaşımına gidilmiş ve ilk düzenlemeler İngiltere de yapılmış, sonrasında ise Fransa'da yasalar çıkarılmış devamında ise Haussman'ın Paris Planı (Güzel Kent Yaklaşımı) gerçekleşmiştir. Bu akım ile birlikte kentlerde anlamsal değerleri olan meydanlar ve anıtlar yapılmaya başlanmıştır. Bunun yanı sıra güzel kent yaklaşımı kenti güzelleştirecek kamusal alanların ve havuzların kurulmasına yönelik bir anlayışı da içinde barındırmıştır (Tekeli, 2011). Devamında Haussman'a tepki olarak Ebenezer Howard'ın başını çektiği "Bahçe-Kent" (Garden-City) ve Le Corbusier'in Paris uygulanmamış planı Plan Voisin yaklaşımları ortaya çıkmıştır. Bu yaklaşımlara rağmen mimarlık ve kent planın pozitivist kimlik kazanması ve güzellik kavramının ikinci planda kalması mimari ve kent planlarının yeniden sorgulanmasına neden olmuştur.

Modernizme tepki olarak ortaya çıkan Postmodernist yaklaşımında ise, modern kentin olumsuz, yorucu, tüketici ve planlamaya dayanan yönlerine vurgu yapılmaktadır. Aslında postmodernizmin diğer alanlarda olduğu gibi, mimarlık ve kentleşme alanında da elle tutulur bir şey söylemediğini, bazı sorunların varlığını saptadığını, ancak gözle görülür kentsel ve toplumsal sorunlara çözüm üretemediğini, özgürlük ve demokrasi söylemlerinin ise, somut düzeyde yalnızca "söylem"den ibaret olduğu savunulmaktadır (Sevinç, 1999).

Kentsel tasarım akımlarından kentler etkilenmiştir. Dolayısıyla çevre kaynakları, doğal kültürel değerler ve kent yaşam kalitesi estetik anlamda düşmüştür. Kentte yaşayan insanlar için doğa ve açık-yeşil alanlar nefes alınan, psikolojik rahatlama sağlayan vazgeçilmez mekankar haline gelmiştir ve estetik bağlamda yaşam kalitesini iyileştirme hususunda sürdürülebilir kentler kavramı gündeme gelmiştir. Fakat bütüncül anlamda estetik kentleri oluşturmak oldukça güç olmuştur. Kent estetiğini etkileyen olumsuz biçimlenmeler kentin bir bütün olarak düşünülmemesinden veya bütünlüğün bilincine varılmadan sorunlara çözümler aranmasından kaynaklanmaktadır (Kumbaracıbaşı, 1991).

Kentsel çevreler sadece insanın biyolojik gereksinmelerini karşılayan işlevsel alanlar değil ayrıca psikolojik, entelektüel gereksinmelerini de karşılayacak estetik nitelikler de taşımalıdırlar. Estetik niteliklere sahip kent, şehir hayatında başa çıkmak zorunda olunan kargaşa ve kaostan bir nebze huzura ve psikolojik açıdan rahatlamaya olanak sağlayacaktır. Estetik kentler aynı zamanda bir kimliğe sahip kent imajı oluşmuş kentlerdir. Kimliği oluşmuş kentler ise, diğer kentlerden ayrılarak, kent sakinlerine kültürlerini yansıtır ve tercih ettikleri yaşam alanlarında çevre değerleriyle yaşama bilinci sunar.

Bu çalışma ile estetik niteliği kazanmış kentlerin, kent bilincinin geliştiği daha huzurlu, daha sağlıklı kentsel yaşam alanları oluşturacağı hipotezinden yola çıkılmıştır. Kullanıııları tarafından çevresel algı ve kent estetiğine yönelik görüşlerinin araştırııması amacıyla, Antalya kentinde aktif olarak kullanılan Güllük Caddesi ve devamında yer alan Cumhuriyet Meydanı, Kapalı Yol mevkileri çalışma alanı olarak belirlenmiştir. 


\section{Materyal ve Yöntem}

\subsection{Materyal}

Araştırma alanı olarak 2 milyonu aşkın nüfusa sahip Antalya kentinin Muratpaşa Illçesinde, aktif kullanıma sahip olan Güllük Caddesi devamında yer alan Cumhuriyet Meydanı akabinde gelen Kapalı Yol mevki çalışma alanı olarak belirlenmiştir.

Antalya'nın en bilindik yerlerinden biri olan Cumhuriyet Meydanı yerli ve yabancı turistleri şehir merkezine getiren tur otobüslerinin bu civardaki durak noktasıdır. Kaleiçi ve yat limanın hemen üst kısmında bulunmaktadır. 1964 Yılında kurulmuş meydanda Ulusal Yükseliş Anıtı yer almaktadır. Antalya'nın en işlek caddelerinden biri olan Güllük Caddesi, Konyaaltı Caddesinin başladığı yerde deniz kıyısından yukarı çıkan caddedir. Yıllardan beri resmi adı "Anafartalar Caddesi" olmasına rağmen hala halk arasında "Güllük Caddesi" olarak söylenmektedir. Kapalı yol mevki ise trafiğe kapatılmış kontrollü geçişlerin sağlandığı Antalya'nın en işlek mevkilerindendir. Sağlı sollu ticaret merkezlerini barındıran mevki birçok yerli ve yabancı turistin uğrak noktasıdır (Şekil 1,2) (Çizelge 1).

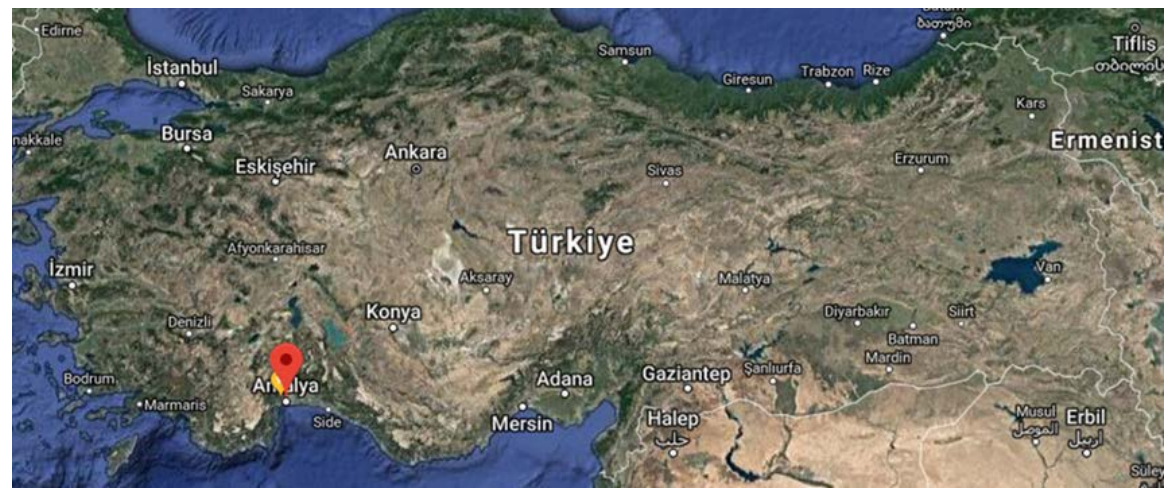

Şekil 1. Antalya ilinin Türkiye Üzerindeki Konumu

Antalya, Türkiye'nin en kalabalık beşinci şehridir. 2018 Yılı itibarıyla il nüfusu 2.426 .356 kişiye ulaşmıştır. İlin yüzölçümü 20.177 km²'dir ve ilde km²'ye 115 kişi düşmektedir. Çalışma alanı olan Muratpaşa İlçesi'nin nüfusu ise $495.688^{\prime}$ dir.

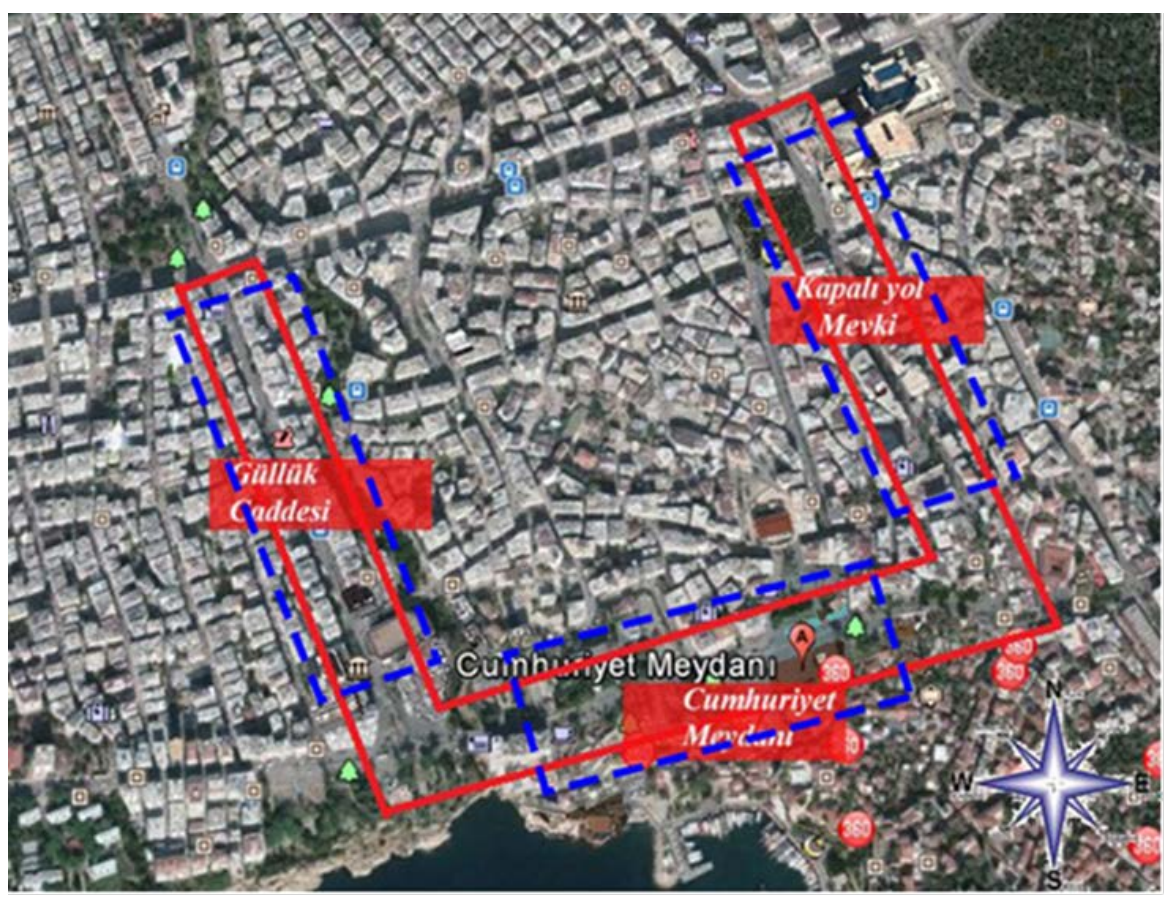

Şekil 2. Antalya Üzerinde Çalışma Alanının Konumu 
Çizelge 1. Çalışma Alanının Koordinat ve Harita Konumu

\begin{tabular}{|c|c|c|c|}
\hline & $\begin{array}{l}\text { Cumhuriyet } \\
\text { Meydanı }\end{array}$ & $\begin{array}{l}\text { Güllük Caddesi } \\
\text { (Anafartalar Caddesi) }\end{array}$ & $\begin{array}{l}\text { Kapalı Yol } \\
\text { (Eski Şarampol Caddesi) }\end{array}$ \\
\hline $\begin{array}{l}\text { Harita } \\
\text { Konumu }\end{array}$ & $\begin{array}{l}\text { Enlem: } 36.8865 \\
\text { Boylam: } 30.7031\end{array}$ & $\begin{array}{l}\text { Enlem: } 36.887444 \\
\text { Boylam: } 30.696789\end{array}$ & $\begin{array}{l}\text { Enlem: } 36.8929 \\
\text { Boylam: } 30.7036\end{array}$ \\
\hline $\begin{array}{l}\text { Coğrafi } \\
\text { Konumu }\end{array}$ & 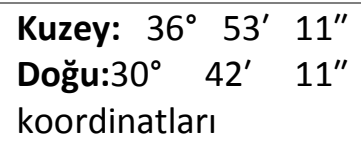 & $\begin{array}{l}\text { Kuzey: } 36^{\circ} 53^{\prime} 14.7984 " \\
\text { Doğu:30 } 41^{\prime} \quad 48.4404^{\prime \prime} \\
\text { koordinaları }\end{array}$ & $\begin{array}{lrl}\text { Kuzey: } 36^{\circ} & 53^{\prime} & 21^{*} \\
\text { Doğu:30 } & 42^{\prime} & 16^{*} \\
\text { koordinatları } & & \end{array}$ \\
\hline $\begin{array}{l}\text { Semt } \\
\text { Mahalle }\end{array}$ & $\begin{array}{l}\text { Selçuk Mahallesi } \\
\text { Muratpaşa İlçesi }\end{array}$ & $\begin{array}{l}\text { Deniz Mahallesi } \\
\text { Muratpaşa İlçesi }\end{array}$ & $\begin{array}{l}\text { Muratpaşa Mahallesi } \\
\text { Muratpaşa İlçesi }\end{array}$ \\
\hline
\end{tabular}

\subsection{Yöntem}

Kentlerde estetik boyut değerlendirilirken genellikle iki farklı yöntem kullanılmaktadır. Bunlardan ilki öznel anlamda eleştiri, yorum yapılarak kullanılan anketler ve şematik anlatımlarken (anketler), diğeri ise nesnel anlamda analizler yapılarak ortaya koyulan entropidir.

Çalışmada öznel değerlendirmeler yapılmış ve anket yöntemi kullanılmıştır. Anket uygulamasının hızlı, güvenilir ve katılımcıların fikirlerini daha rahat belirtecekleri ortamı sağlamak için internet üzerinden yapılması tercih edilmiştir. Katılımcılara yanıtlarını aktarabilecekleri bir form oluşturularak internet üzerinden anketler değerlendirilmiştir. Anketlerin içeriği katılımcıların demografik özelliklerini içeren sorular ve çalışma alanlarının kullanma tercihlerini yansıtan sorularla, çalışma alanındaki mekânsal öğelere yönelik estetik niteliğini ortaya koyan analizlerinden oluşmaktadır.

Anket yapılacak denek sayısı, Antalya ili Muratpaşa ilçesi kent merkezi nüfusu dikkate alınarak \% 95 güven aralığında 120 olarak belirlenmiştir. Bu rakamın hesaplanmasında aşağıdaki formül kullanılmıştır (Kalıpsız, 1981).

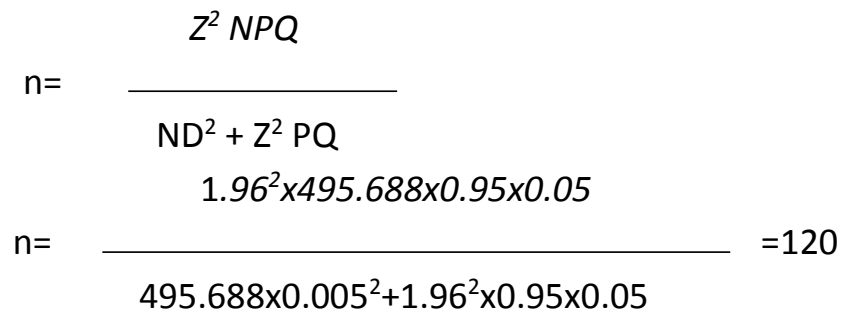

$\mathrm{n}=$ Örnek büyüklüğü

Z= Güven katsayısı

$\mathrm{P}=$ Ölçmek istediğimiz özelliğin kütlede bulunma ihtimali (çalışmada 95 olarak alınmıştır)

$\mathrm{Q}=1-\mathrm{P}$

N= Ana kütle büyüklüğü (495.688)

Yapılan formül hesaplamasında uygulanacak denek sayısı 120 çıkmasına rağmen çalışmanın güvenilirliğinin arttııı ması açısından halka yönelik 350 kişiye anket çalışması yapıımıştır. 


\section{Bulgular ve Tartışma}

\subsection{Demografik özelliklere ait bulgular}

Toplam 350 gönüllü birey, araştırma kapsamında anket uygulamasına katılmıştır (Çizelge 2).

Çizelge 2. Demografik bilgilere ait kişi dağılımları ve yüzde tablosu

\begin{tabular}{|c|c|c|}
\hline Demografik Özellikler & Kişi & Yüzde (\%) \\
\hline \multicolumn{3}{|l|}{ Cinsiyetiniz ? } \\
\hline Kadın & 176 & 50,3 \\
\hline Erkek & 174 & 49,7 \\
\hline Toplam & 350 & 100 \\
\hline \multicolumn{3}{|l|}{ Yaşınız? } \\
\hline $18-25$ & 135 & 38,6 \\
\hline $26-33$ & 76 & 21,7 \\
\hline $34-41$ & 53 & 15,1 \\
\hline $42-49$ & 30 & 8,6 \\
\hline $50-57$ & 38 & 10,9 \\
\hline $58-65$ & 11 & 3,1 \\
\hline $65+$ & 7 & 2 \\
\hline Toplam & 350 & 100 \\
\hline \multicolumn{3}{|l|}{ Eğitim durumunuz? } \\
\hline Illk Öğretim (ilk Okul) & 31 & 8,9 \\
\hline Orta Öğretim (Lise) & 90 & 25,7 \\
\hline Lisans (Üniversite) & 202 & 57,7 \\
\hline Yüksek Lisans & 24 & 6,9 \\
\hline Doktora & 3 & 0,8 \\
\hline Toplam & 350 & 100 \\
\hline \multicolumn{3}{|l|}{ İş durumunuz? } \\
\hline Çalışıyor & 205 & 58,6 \\
\hline Çalışmıyor & 145 & 41,4 \\
\hline Toplam & 350 & 100 \\
\hline \multicolumn{3}{|l|}{ Ekonomik geliriniz ? } \\
\hline$\ldots<2.500$ & 195 & 55,7 \\
\hline $2.500-5.000$ & 92 & 26,3 \\
\hline $5.000<\ldots$ & 63 & 18 \\
\hline Toplam & 350 & 100 \\
\hline
\end{tabular}

Anket katılımcılarının soruları bağımsız olarak yanıtlamaları açısından 18 yaş üstü katılımcı profili ankete dahil edilmiştir. Katılımcıların \% 38,6'sının $18-25$ yaş aralığında olduğu görülmektedir. Görüldüğü üzere anket katılımcılarının \% 57,7'si lisans düzeyinde eğitim almıştır. İş durumu incelendiğinde \% 58,6'sının çalışıyor olduğu görülmektedir. Ekonomik gelirleri incelendiğine \% $55,7^{\prime} \operatorname{sinin} 2.500$ 'ün altında gelire sahip olduğu görülmektedir.

Katılımcılara 'Mesleğiniz nedir?' açık uçlu sorusu sorulduğunda; tıp, eğitim, inşaat, ticaret gibi birçok sektörde meslek dağılımı olduğu görülmüştür.

\subsection{Kavramsal temellere ait bulguları}

Anket katılımcılarının; kavramsal temellere yönelik kullanıcı tercihleri irdelenmiştir ve estetik bir meydan ve estetik bir cadde nasıl olmalı sorusunun yanıtı aranmıştır (Çizelge 3). 
Çizelge 3. Kavramsal temellere yönelik kullanıcı istekleri

\begin{tabular}{lll}
\hline Kavramsal Temellere Yönelik Kullanıcı Tercihleri & Kişi & Kişi \\
\hline Estetik bir meydan sizce nasıl olmalıdır ? & & \\
Göze hoş görünmeli & 108 & 30,9 \\
Bir çok kullanım (fonksiyon)içermeli & 87 & 24,9 \\
Doğal malzemeler kullanılmalı & 49 & 14 \\
Çevre içinde farkedilmeli & 31 & 8,9 \\
Sanatsal değeri olmalı & 75 & 21,4 \\
\hline Estetik bir cadde sizce nasıl olmalıdır ? & & \\
Göze hoş görünmeli & 152 & 43,4 \\
Bir çok kullanım (fonksiyon)içermeli & 89 & 25,4 \\
Doğal malzemeler kullanılmalı & 32 & 9,1 \\
Çevre içinde farkedilmeli & 36 & 10,3 \\
Sanatsal değeri olmalı & 41 & 11,7 \\
\hline
\end{tabular}

Anket katılımcılarının 'Estetik bir meydan ve estetik bir cadde nasıl olmalıdır?' sorusuna katılımcıların \% 30,9'unun estetik bir meydan göze hoş görünmeli yanıtını, \% 43,4'ünün estetik bir cadde göze hoş görünmeli yanıtını verdiği görülmektedir.

\section{3. Çalışma alanlarına ait bulgular}

Anket katılımcılarının alan kullanma tercihleri sorgulanmaktadır. Çizelge 4.'de alan kullanım sıklıkları ve tercih edilen saat dilimleri kişi sayıları ve yüzde dağılımları ile birlikte gösterilmektedir.

Çizelge 4. Alan kullanım tercihleri

\begin{tabular}{lllllll}
\hline Alan Kullanım Tercihleri & \multicolumn{2}{l}{$\begin{array}{l}\text { Kapalı } \\
\text { Yol }\end{array}$} & \multicolumn{3}{l}{$\begin{array}{l}\text { Cumhuriyet } \\
\text { Meydanı }\end{array}$} & Güllük Caddesi \\
& Kişi & Yüzde(\%) & Kişi & Yüzde(\%) & Kişi & Yüzde(\%) \\
Alanı kullanma sıklığınız? & & & & & & \\
Hergün (Çok sık) & 15 & 4,3 & 16 & 4,6 & 23 & 6,6 \\
Haftada iki (Sık) & 45 & 12,9 & 39 & 11,1 & 37 & 10,6 \\
Haftada bir (Genellikle) & 54 & 15,4 & 61 & 17,4 & 51 & 14,6 \\
Ayda iki-üç (Bazen) & 82 & 23,4 & 73 & 20,9 & 77 & 22 \\
Ayda bir (Seyrek) & 69 & 19,7 & 77 & 22 & 73 & 20,9 \\
Iki ayda bir (Çok seyrek) & 73 & 20,9 & 75 & 21,4 & 78 & 22,3 \\
ilk defa & 12 & 3,4 & 9 & 2,6 & 11 & 3,1 \\
\hline Alanı hangi saat dilimlerinde & & & & & & \\
daha çok kullanıyorsunuz ? & & & & & & \\
07.00-12.00 & 51 & 14,6 & 39 & 11,1 & 56 & 16 \\
12.00-18.00 & 205 & 58,6 & 181 & 51,7 & 221 & 63,1 \\
18.00-24.00 & 181 & 51,7 & 211 & 60,3 & 176 & 50,3 \\
24.00-07.00 & 14 & 4 & 15 & 4,3 & 12 & 3,4 \\
\hline
\end{tabular}

'Kapalı Yolu kullanma sıklığınız nedir?' sorusuna anket katılımcılarının \% 23,4'ünün ayda iki-üç (bazen) cevabını verildiği görülmektedir. 'Cumhuriyet Meydanını kullanma sıklığınız nedir?' sorusuna katılımcıların \% 21,4'ünün iki ayda bir (çok seyrek) yanıtını verdiği görülmektedir. 'Güllük Caddesini kullanma sıklığınız nedir?' sorusuna katıımcıların \% 22,3'ünün iki ayda bir (çok seyrek) yanıtını verdiği görülmektedir.

Katılımcılara 'Hangi zaman diliminde Kapalı Yolu kullanmayı tercih edersiniz?' sorusu sorulduğunda; \% 58,6'sının 12.00-18.00 saat dilimlerinde kullanmayı tercih ettiği görülmektedir. 'Hangi zaman diliminde Cumhuriyet Meydanını kullanmayı tercih edersiniz?' sorusu sorulduğunda \% 60,3'ünün 18.00-24.00 saat dilimlerinde kullanmayı tercih ettiği görülmektedir. Katılımcılara 'Hangi zaman diliminde Güllük Caddesini kullanmayı tercih edersiniz?' sorusu sorulduğunda \% 63,1'inin 12.00-18.00 saat dilimlerinde kullanmayı tercih ettiği görülmektedir. 
Anket katılımcılarının alanın bıraktığı etki ve izlenimler sorgulanmaktadır. Çizelge 5.'te alanların uyandırdığı psikolojik etki, fonksiyonel memnuniyet durumu, en beğenilen karakteristik özellikler kişi sayıları ve yüzde dağılımları ile birlikte gösterilmektedir.

Çizelge 5. Alanların kullanıcılarda bıraktığı izlenimler

\begin{tabular}{|c|c|c|c|c|c|c|}
\hline \multirow[t]{2}{*}{$\begin{array}{l}\text { Alanın Kullanıcılarda } \\
\text { Bıraktığı İzlenim }\end{array}$} & \multicolumn{2}{|c|}{$\begin{array}{l}\text { Kapalı } \\
\text { Yol }\end{array}$} & \multicolumn{2}{|c|}{$\begin{array}{l}\text { Cumhuriyet } \\
\text { Meydanı }\end{array}$} & \multicolumn{2}{|c|}{ Güllük Caddesi } \\
\hline & Kişi & Yüzde(\%) & Kişi & Yüzde(\%) & Kişi & Yüzde(\%) \\
\hline \multicolumn{7}{|l|}{$\begin{array}{l}\text { Alan sizde nasıl bir } \\
\text { psikolojik etki uyandırıyor? }\end{array}$} \\
\hline Sıkıntı verici ve hayal kırıklığı & 131 & 37,4 & 29 & 8,3 & 137 & 39,1 \\
\hline Heyecan verici & 29 & 8,3 & 97 & 34 & 34 & 9,7 \\
\hline Mutluluk verici & 93 & 26,6 & 84 & 24 & 87 & 24,9 \\
\hline Korku ve kaygı verici & 26 & 7,4 & 10 & 2,9 & 23 & 6,6 \\
\hline Rahatlatıcı & 57 & 16,3 & 174 & 49,7 & 52 & 14,9 \\
\hline Güven verici & 14 & 4 & 19 & 5,4 & 17 & 4,9 \\
\hline \multicolumn{7}{|l|}{$\begin{array}{l}\text { Alandaki fonksiyonlar } \\
\text { beklentilerinizi } \\
\text { karşılıyor mu? }\end{array}$} \\
\hline Hiç memnun değilim & 25 & 7,1 & 7 & 2 & 35 & 10 \\
\hline Memnun değilim & 76 & 21,7 & 35 & 10 & 69 & 19,7 \\
\hline Çok memnunum & 26 & 7,4 & 39 & 11,1 & 24 & 6,9 \\
\hline Memnunum & 180 & 51,4 & 239 & 68,3 & 178 & 50,9 \\
\hline Fikrim yok & 43 & 12,3 & 30 & 8,6 & 44 & 12,6 \\
\hline \multicolumn{7}{|l|}{$\begin{array}{l}\text { Alanda en beğendiğiniz } \\
\text { karakteristik özellik nedir? }\end{array}$} \\
\hline Sokaklar ve cadde kimliği & 204 & 58,3 & 89 & 25,4 & 174 & 49,7 \\
\hline Bitki örtüsü & 31 & 8,9 & 38 & 10,9 & 28 & 8 \\
\hline Su öğesi & 42 & 12 & 128 & 36,6 & 28 & 8 \\
\hline Mimari yapı & 68 & 19,4 & 184 & 52,6 & 50 & 14,3 \\
\hline Donatılar & 48 & 13,7 & 48 & 13,7 & 49 & 14 \\
\hline Diğer & 62 & 17,7 & 49 & 14 & 115 & 32,9 \\
\hline
\end{tabular}

Anket katılımcılarına 'Kapalı Yol sizde nasıl bir psikolojik etki uyandırıyor?' sorusu sorulduğunda katılımcıların \% 37,4'ünün Kapalı Yolun psikolojik olarak sıkıntı verdiği ve hayal kırıklığı yaşattığı görülmektedir. 'Cumhuriyet Meydanını sizde nasıl bir psikolojik etki uyandırıyor?' sorusu sorulduğunda katılımcıların \% 49,7'sinde Cumhuriyet Meydanının psikolojik olarak rahatlama etkisi yarattığı görülmektedir. 'Güllük Caddesi sizde nasıl bir psikolojik etki uyandırıyor?' sorusu sorulduğunda katılımcıların \% 39,1'ininde Güllük Caddesinin psikolojik olarak sıkıntı verdiği ve hayal kırıklığı yaşattığı görülmektedir.

Anket katılımcılarına 'Kapalı Yoldaki fonksiyonlar beklentinizi karşılıyor mu?' sorusu sorulduğunda katılımcıların \% 51,4'ü 'memnun' yanıtı vermiştir. 'Cumhuriyet Meydanındaki fonksiyonlar beklentinizi karşılıyor mu?' sorusu sorulduğunda; katılımcıların \% 68,3'ü 'memnun' yanıtı vermiştir. "Güllük Caddesindeki fonksiyonlar beklentinizi karşılıyor mu?" sorusu sorulduğunda; katılımcıların \% 50,9'u 'memnun' yanıtı vermiştir. Dolayısıyla her üç alan kullanıcıları da alanlarda bulunan fonksiyonlardan memnunum yanıtını vermiştir ve alanların beklentileri karşıladığı görülmektedir.

Katılımcılara 'Kapalı Yolda en beğendiğiniz karakteristik özellik nedir?' sorusu sorulduğunda katılımcıların \% 58,3'ünün 'sokaklar ve cadde kimliği' yanıtı verdiği görülmektedir. 'Cumhuriyet Meydanında en beğendiğiniz karakteristik özellik nedir?' sorusu sorulduğunda katılımcıların \% 52,6'sının 'mimari yapı' yanıtı verdiği görülmektedir. 'Güllük Caddesinde en beğendiğiniz karakteristik özellik nedir?' sorusu sorulduğunda katılımcıların \% 49,7'sinin 'sokaklar ve cadde kimliği' yanıtı verdiği görülmektedir. 
Anket katılımcılarının alanları kullanım amaçları irdelenmektedir. Çizelge 6.'da alanların kullanım amaçları kişi sayıları ve yüzde dağılımları ile birlikte gösterilmektedir.

Çizelge 6. Alanların kullanım amaçları

\begin{tabular}{|c|c|c|c|c|c|c|}
\hline \multirow[t]{2}{*}{ Alan Kullanım Amaçları } & \multicolumn{2}{|c|}{$\begin{array}{l}\text { Kapalı } \\
\text { Yol }\end{array}$} & \multicolumn{2}{|c|}{$\begin{array}{l}\text { Cumhuriyet } \\
\text { Meydanı }\end{array}$} & \multicolumn{2}{|c|}{ Güllük Caddesi } \\
\hline & Kişi & Yüzde(\%) & Kişi & Yüzde(\%) & Kişi & Yüzde(\%) \\
\hline \multicolumn{7}{|l|}{$\begin{array}{l}\text { Alanı kullanma amacınız } \\
\text { nelerdir? }\end{array}$} \\
\hline Temiz hava almak & 45 & 12,9 & 149 & 42,6 & 17 & 4,9 \\
\hline Dinlenmek ve rahatlamak & 65 & 18,6 & 175 & 50 & 24 & 6,9 \\
\hline Alışveriş yapmak & 219 & 62,6 & 30 & 8,6 & 206 & 58,9 \\
\hline Etrafı seyretmek & 68 & 19,4 & 159 & 54,4 & 41 & 11,7 \\
\hline Birileriyle buluşmak & 80 & 22,9 & 112 & 32 & 60 & 17,1 \\
\hline Günlük işlerimi halletmek & 88 & 25,1 & 40 & 11,4 & 101 & 28,9 \\
\hline Diğer & 6 & 10,3 & 36 & 10,3 & 55 & 15,7 \\
\hline
\end{tabular}

'Kapalı Yolu kullanma amacınız nelerdir?' sorusu sorulduğunda katılımcıların \% 62,6'sının 'kapalı yolu alışveriş yapmak amacıyla' kullandığı görülmektedir. 'Cumhuriyet Meydanını kullanma amacınız nelerdir?' sorusu sorulduğunda; katılımcıların \% 54,4'ünün Cumhuriyet Meydanını dinlenmek ve rahatlama amacıyla kullandığı görülmektedir. 'Güllük Caddesini kullanma amacınız nelerdir' sorusu sorulduğunda; katılımcıların \% 58,9'unun Güllük Caddesini alışveriş yapmak amacıyla kullandığı görülmektedir.

Anket katılımcılarının alanlara yönelik istekleri ve gerekli gördüğü düzenlemeler saptanmıştır. Çizelge 7.'de alanlarda kullanıcı istek ve gerekli bulunan düzenlemeler kişi sayıları ve yüzde dağııımları ile birlikte gösterilmektedir.

Çizelge 7. Alan kullanıcı istekleri

\begin{tabular}{lllllll}
\hline $\begin{array}{l}\text { Alan Kullanıcılarının } \\
\text { Istekleri }\end{array}$ & \multicolumn{2}{l}{$\begin{array}{l}\text { Kapalı } \\
\text { Yol }\end{array}$} & \multicolumn{3}{l}{$\begin{array}{l}\text { Cumhuriyet } \\
\text { Meydanı }\end{array}$} & Güllük Caddesi \\
\hline $\begin{array}{l}\text { Alanın nasıl olmasını } \\
\text { isterdiniz ? }\end{array}$ & Kişizde(\%) & Kişi & Yüzde(\%) & Kişi & Yüzde(\%) \\
Daha renkli & 141 & 40,3 & 152 & 43,3 & 107 & 30,6 \\
Daha renksiz & 2 & 0,6 & 0 & 0 & 3 & 0,9 \\
Daha kompleks & 31 & 8,9 & 40 & 11,4 & 64 & 18,3 \\
Daha basit & 15 & 4,3 & 3 & 0,9 & 28 & 8 \\
Daha büyük & 61 & 17,4 & 48 & 13,7 & 68 & 19,4 \\
Daha küçük & 3 & 0,9 & 2 & 0,6 & 3 & 0,9 \\
Daha doğal & 93 & 26 & 103 & 29,4 & 75 & 21,4 \\
Daha yapay & 4 & 1,1 & 2 & 0,6 & 2 & 0,6 \\
\hline
\end{tabular}

'Kapalı Yolun nasıl olmasını isterdiniz?' sorusu sorulduğunda katılımcıların \% 40,3'ünün daha renkli yanıtı verdiği görülmektedir. 'Cumhuriyet Meydanının nasıl olmasını isterdiniz?' sorusu sorulduğunda katıımcıların \% 43,3'ünün 'daha renkli' yanıtı verdiği görülmektedir. 'Güllük Caddesinin nasıl olmasını isterdiniz?' sorusu sorulduğunda katılımcıların \% 30,6'sının daha renkli yanıtı verdiği görülmektedir. Dolayısıyla anket katıımcıları tarafından her üç alanında daha renkli olması istenmektedir.

Anket katılımcılarına 'Kapalı Yolda hangi düzenlemelere yer verilmelidir?' sorusu sorulduğunda katılımcıların \% 74,3'ünün kapalı yolda 'bitki düzenlemesine (peyzaj çalışmalarına)' yer verilmeli yanıtını verdiği görülmektedir (Şekil 3). 


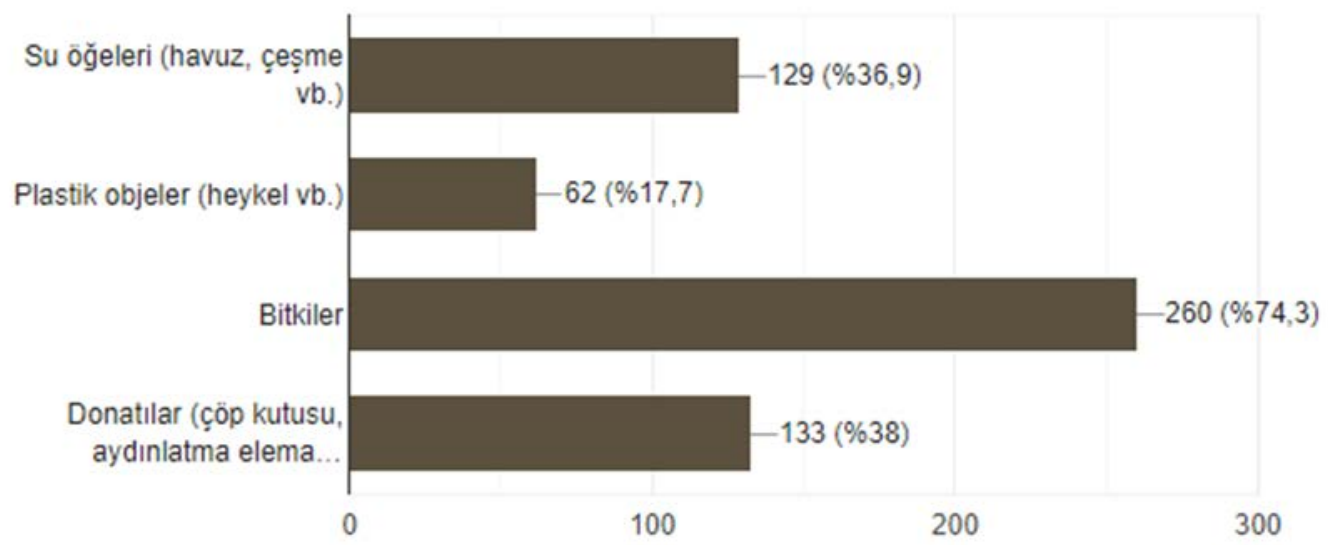

Şekil 3. Kapalı Yolda İstenen Düzenleme Elemanları (\%)

Anket katılımcılarına 'Cumhuriyet Meydanında hangi düzenlemelere yer verilmelidir?' sorusu sorulduğunda katılımcıların \% 76,9'unun Cumhuriyet Meydanı'nda 'bitki düzenlemesine (peyzaj çalışmalarına)’ yer verilmeli yanıtını verdiği görülmektedir (Şekil 4).

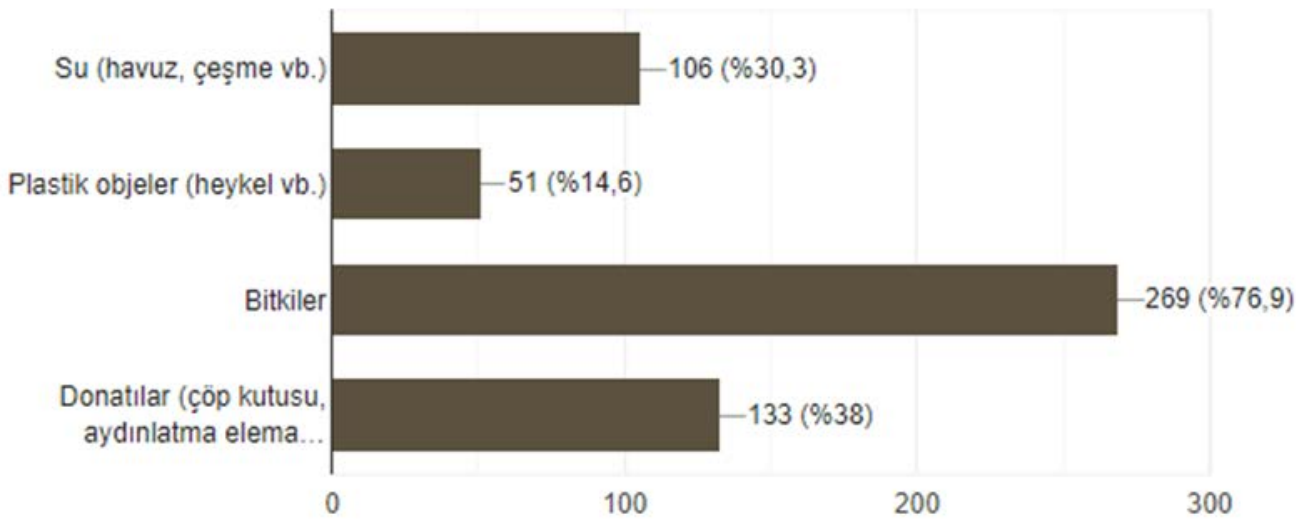

Şekil 4. Cumhuriyet Meydanında İstenen Düzenleme Elemanları (\%)

Anket katılımcılarına 'Güllük Caddesinde hangi düzenlemelere yer verilmelidir?' sorusu sorulduğunda katılımcıların \% 68,6'sının Güllük Caddesi'nde 'bitki düzenlemesine (peyzaj çalışmalarına)” yer verilmeli yanıtını verdiği görülmektedir (Şekil 5).

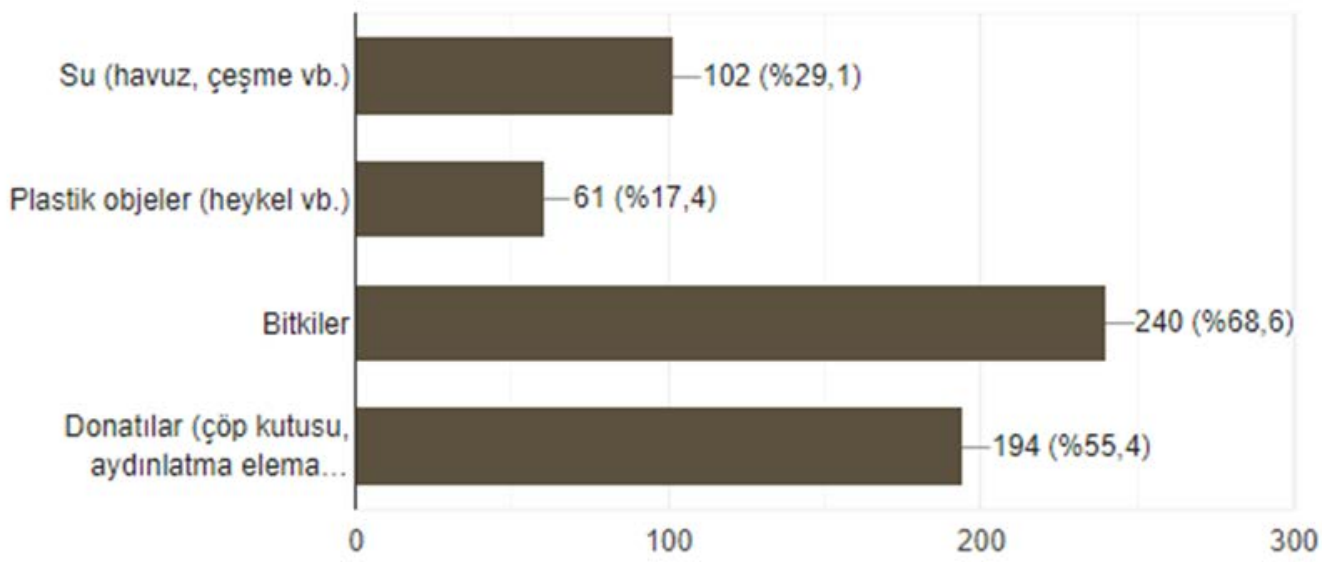

Şekil 5. Güllük Caddesinde İstenen Düzenleme Elemanları (\%)

Dolayısıyla anket katılımcıları tarafından her üç alanda da çoğunlukla bitki düzenlemesine (peyzaj çalışmalarına) yer verilmeli yanıtı verdiği görülmektedir. 
'Kapalı Yolda hoşlandığınız şeyler nelerdir?' açık uçlu sorusuna genellikle alışveriş, hareketlilik ve kalabalık, trafiğe kapalı olması, erişim ve ulaşılabilirlik, konum ve mimari yapısı gibi yanıtlar gelmiştir. 'Kapalı Yolda hoşlanmadığınız şeyler nelerdir?' açık uçlu sorusuna genellikle kalabalık, dar, yetersiz, çarpık kentleşme, sıkıcı, estetik değil, işlevsiz, esnaf ve seyyar satıcılar, güvensiz, otopark sorunu, donatı eksikliği, gürültü gibi yanıtlar gelmiştir.

'Cumhuriyet Meydanından hoşlandığınız şeyler nelerdir?' açık uçlu sorusuna genellikle manzara, heykel, deniz, sakinlik ve huzur, temiz hava ve mimari yapı yanıtları gelmiştir. 'Cumhuriyet Meydanından hoşlanmadığınız şeyler nelerdir?' açık uçlu sorusuna genellikle beton yığını, bitki az, peyzaj eksik, genel yetersizlik, otopark sorunu, donatı yetersizliği, estetik değil, yapay, dilenci ve falcılar gibi yanıtlar gelmiştir.

'Güllük Caddesinden hoşlandığınız şeyler nelerdir?' açık uçlu sorusuna genellikle alışveriş, gezmek, erişim ve ulaşım gibi yanıtlar gelmiştir. 'Güllük Caddesinde hoşlanmadığınız şeyler nelerdir?' açık uçlu sorusuna kalabalık, kaldırım ve seyyar satıcılar, genel yetersizlik, trafik, estetik değil, dar, trafiğe kapatılmalı, mimarisi, donatılar, yapay, bitki eksikliği gibi yanıtlar gelmiştir.

\section{Sonuç ve Öneriler}

Kullanıcıların kavramsal temellere ait istekleri göz önünde bulundurulduğunda estetik bir meydan ve estetik bir cadde göze hoş görünmeli yanıtını verdikleri görülmektedir. Estetik algısında önce göze hitap bu bağlamda önemlidir. Nitekim görme duyusu duyularımız arasında algının en hızlı gerçekleştiği duyudur. Estetik algısının oluşumunda da göze hitap oldukça büyük bir öneme sahiptir. Estetik bir meydan ya da cadde oluştururken göze hitap eden estetik niteliklere sahip tasarımlar yapmaya özen göstermeliyiz.

Kapalı Yol ve Güllük Caddesinin uyandırdığı psikolojik etki sorulduğunda anket katılımcılarında genel olarak sıkıntı verici ve hayal kırıklığı uyandırdığı görülmektedir. Bu bağlamda alanları değerlendirmek gerekmektedir. Kapalı Yol ve Güllük Caddesinin anket sonuçlarına göre sıkıntı verici ve hayal kırıklığı hissi uyandırmasının temel sebeplerinden birisi yoğun bir kullanıma sahip olmalarıdır. Birçok kullanımı içeren alanlar oldukça kalabalık ve dardır. Dolayısıyla insanlar istedikleri gibi hareket etmekte zorlanmakta ve istediği kullanımlara erişmekte sınırlanmaktadırlar. Yanı sıra estetik anlamda levha kirliliği ve düzensizlik oldukça fazladır. Oysaki ticari levhaların cadde ve sokaklarda; renk, doku, tekstür, şekil ve biçim gibi özellikleri bulunduğu yerin mevcut yapısına uygun şekilde tercih edilmesi kent estetiğine olumlu katkıda bulunacaktır. Ticari levha kirliği kent estetiğine olumsuz katkıda bulunmaktadır. Bu bağlamda işletmeler tek tip levha kullanımına geçmelidir. Aynı zamanda binaların dış cephesinin genel görünümlerinin kent estetiğine katkıda bulunabilmesi için restorasyon, iyileştirme gibi düzenlemeler yapılması gerekmektedir. Kimliksiz ya da anlam içeriğine sahip olmadan kullanılan objeler alandan soyutlanmakta ve yabancılaşmaktadır ve zamanla göze hitap etmemektedir. Bu açıdan kullandığımız obje ve heykellerin alanla entegrasyonunu göz önünde bulundurulmalı ve tercihlerin o yönde yapmasına özen gösterilmelidir.

Cumhuriyet Meydanının uyandırdığı psikolojik etki sorulduğunda ise rahatlatıcı etki uyandırdığını ifade edilmektedir. Bunun temel nedeni alanın bulunduğu konumdur. Çünkü alanda Antalya ile bütünleşmiş ve kimlik kazanmış bir heykel bulunmaktadır. Antalya ile bütünleşerek değerlenmiş ve kimlik kazanmış heykelin kent estetiğine katkısı büyüktür. Aynı zamanda alanda deniz manzarası bulunmaktadır. Su öğesi, kamusal park ve meydanlar gibi kentsel çevrelerde inşaa edilmiş su elemanları olup; kent peyzajlarımızda suyun rolünü ortaya koymaktadır. İnsanların suyun özelliklerini dokunma, görme ve ses yoluyla deneyimlemesine olanak sağlarlar dolaysıyla da bu şekilde yaklaşımın arkasındaki gerekçe insanların suyun güzellikleri ile ilişki kurabilecekleri sürdürülebilir ve güzel kentsel açık alanlar üretmektir.

Alanlarda en beğenilen karakteristik özelliklerde Kapalı Yol ve Güllük Caddesinde katılımcılar çoğunlukla sokak ve cadde kimliğini tercih etmektedir. Çünkü Güllük Caddesi ve Kapalı Yol tek güzargah üstü cadde ve yoldan oluşmaktadır. Cumhuriyet Meydanında ise anket katılımcıları tarafından mimari yapı tercih edilmektedir. Katılımcılar Kapalı Yol ve Güllük Caddesi'ni genellikle alışveriş yapmak amacıyla kullanırken Cumhuriyet Meydanı'nı ise dinlenmek ve rahatlamak amacıyla kullanılmaktadır. 
Alanlarda bulunan fonksiyonel özelliklerden katılımcılar memnundur ve alanlar kullanıcıların beklentilerini karşılamaktadır. Alanlarda katılımcılara göre genellikle bitki düzenlemelerine (peyzaj tasarımına) yer verilmelidir. Kentsel çevrelerde tasarımlarda kullandığımız bitkiler gerek sonbahar, gerekse ilkbahar renklenmesiyle adeta gözlerimizde renk şöleni oluşturmaktadır.

Kapalı Yolun dar, kalabalık, yetersiz olduğu anket katılımcıları tarafından düşünülmektedir. Cumhuriyet Meydanı katılımcılar tarafından sert zemini bol olması, peyzaj uygulamalarının ve donatı elemanlarının eksik olması yönünden eleştirilmiştir. Güllük Caddesi anket katılımcıları tarafından kaldırımları, trafiği, kalabalığı, peyzaj uygulama eksikliği yönünden eleştirilmiştir. Bu bağlamda yerinde çalışmalar yapılarak gerekli düzenlemeler yapılmalıdır. Nitekim çalışmaların yapııması ile çevre bilinci oluşacak, kentsel yaşam kalitesi artacak ve kentsel estetik açısından birçok kazanım elde edilecektir.

\section{Kaynaklar}

Kalıpsız, A., (1981). İstatistik Yöntemler, İstanbul Üniversitesi. Orman Fakültesi, Yayın No: 2837, Orman Fakültesi, Yayın No:294, i̇stanbul.

Kumbaracıbaşı, C., (1991). Kent, Estetik, Ankara, “2000'li Yıllar İçin Ankara Kenti'nin Açık ve Yeşil Alan Sistemi Ne Olmalıdır?" Ankara Büyükşehir Belediyesi\&Peyzaj Mimarlı̆̆ı Derneği Sempozyum Bildirileri Ortak Yayını, 29/31 Mayıs, S. 65-67, Ankara.

Sevinç, M., (1999). Postmodernizm ve Kent. Birikim Dergisi, 124.

Tekeli, i. (2011).Türkiye'nin Kent Planlama ve Kent Araştırmaları Tarihi Yazıları.Istanbul: Tarih Vakfı Yurt Yayınları. 